\title{
The Study on the Index System of Classification Assessment and Evaluation of the State-owned Enterprises*
}

\author{
Baifang Liu \\ Business School \\ Beijing Language and Culture University \\ Beijing, China 100083
}

\author{
Li Jiang \\ Business School \\ Beijing Language and Culture University \\ Beijing, China 100083
}

\author{
Xuewei Zhan \\ Business School \\ Beijing Language and Culture University \\ Beijing, China 100083
}

\begin{abstract}
China's historical development and basic national conditions determine that the state-owned enterprises will play a leading role in our national economy in the long run. Different types of the state-owned enterprises have different functions. Therefore, classified assessment of the state-owned enterprises is a necessary requirement for the development of enterprises. On the basis of clarifying classification management theory of the state-owned enterprises, this paper analyzes the existing problems in the assessment of the stateowned enterprises, and draws on the experience of foreign enterprises in the state-owned enterprises management, and finally puts forward the policy suggestions for establishing the evaluation system of the state-owned enterprises in China.
\end{abstract}

Keywords-state-owned enterprises; classification management; assessment; system

\section{INTRODUCTION}

The SASAC, the MFPRC and the National Development and Reform Commission jointly issued the "guiding opinions on the definition and classification of the functions of the state-owned enterprises" in December 29, 2015. According to the main business and core business scope, the stateowned enterprises are defined as commercial and public welfare. In December 12, 2016, the SASAC also issued the "management performance assessment method for the central enterprise leader" which carried out classification assessment for the central enterprises with different enterprise functions and improved the pertinence and effectiveness of performance assessment. The state owned enterprise is an important pillar of the national economy. Establishing and improving the business performance regulatory evaluation system of the state-owned enterprises is an important institutional innovation of the reform of the state-owned assets management system. It should start from

*This Research finding is supported by the special fund of the basic research of the Central University, project number: 16ZDD01. implement the scientific development view in an all-round way and realizing the development strategy of the enterprise and strengthen the establishment of a sound management performance appraisal system. On the basis of the research and understanding of the main problems and contradictions of the current management assessment of the state-owned enterprises, the performance regulatory evaluation system will be speed up the establishment and improvement.

\section{THE THEORETICAL BASIS OF THE CLASSIFIED MANAGEMENT OF STATE-OWNED ENTERPRISES}

In some versions of free-market economics, the stateowned enterprises should only exist in the necessary areas, only do things that private enterprises do not want to do or cannot do by private enterprises. It is aimed at helping the government to accomplish its economic and social functions. This requires that the principle of market failure must be persisted in the establishment of the state-owned enterprises, that is, only in existence. In the field of market failure, it is necessary for the state-owned enterprises to exist. On the other hand, from the theory of property rights, when private property rights are too expensive to maintain their exclusivity, it is necessary to exist in the form of state-owned property rights. In order to realize the public welfare of the society, we should make use of the form of state-owned property right to make up for the defects of the market mechanism in allocating resources.

The existence of the state-owned enterprises in China is very wide. Due to special historical reasons, China's production and management of the state-owned enterprises is the main way of economic construction for a long period, and its management field is almost all over the whole industry of national economy. From the point of view of the state-owned enterprises function in our country at present, the state-owned enterprises should provide public products and services that private capital cannot or do not want to 
provide to the whole society in order to make up for the market failure. At the same time, we must develop innovative private supplies for the changes of economy, social culture, nature, population as well as science and technology and actively participate in market competition. In a specific time and environment, we must set up the phased state-owned enterprises according to national policy orientation, such as some project based on state owned enterprises. The market positioning and management goals of different types of the state-owned enterprises are very different. Therefore, the scientific classification of the stateowned enterprises must be carried out, and the differential management of the state-owned enterprises should be gradually achieved in order to give full play to the advantages and characteristics of all kinds of the state-owned enterprises, and to improve the core competitiveness and comprehensive strength of the state-owned enterprises.

\section{The MAIN PROBLEMS IN THE ASSESSMENT OF THE STATE-OWNED ENTERPRISES AT PRESENT}

The assessment of the state-owned enterprises is a hot topic and difficult point in management. At present, there are some problems in the implementation of performance assessment in most of our state-owned enterprises. The phenomenon of "the mess" is obvious; managers and employees can't participate in enterprises' management authentically. The performance evaluation system of the whole state-owned enterprises can be said to exist in name only, which cannot reach the expectation of assessment, and even caused the brain drain.

\section{A. Performance Appraisal Is Decoupled from the Strategic Objectives of Enterprises in Reality}

The managers of the state-owned enterprises and other performance evaluation subjects have utilitarianism in the management of enterprises. They usually have a myopic attitude, only pay attention to the improvement of business performance and ignore the long-term strategic development of the enterprises. Performance evaluation often focuses on assessing short-term business conditions or operating results over a period of time.

\section{B. The Key Index Is Difficult to Select}

In the selection of the key indicators of performance assessment, the state owned enterprises mainly refer to the Interim Measures for the Management Performance Assessment of the Central Enterprise Leaders issued by the SASAC, mainly including the traditional profit and practical economic added. Thirty indexes including financial indicators and other indicators are given in the implementation details. Although these all provide a basis for the selection of performance evaluation indicators, the fact is that enterprises are still facing many difficulties in the selection of key assessment indicators. In addition, most of these indicators are not quantifiable. The performance assessment of many the state-owned enterprises will focus on the wrong position, take the advantage of the emphasis on "virtue" and "diligence", and do not put the key "performance" and "efficiency" of performance assessment in a correct position. How to select effective assessment indicators appropriately is a core issue faced by enterprises when carrying out performance evaluation.

\section{There Is a Lack of Effective Assessment Methods for the Social Functions of State-owned assets}

The state owned enterprises not only have the business goal of realizing their economic value, but also shoulder the task of realizing some social responsibilities. In the past, the state-owned enterprises in our country did not divide the examination objects, overemphasized the assessment of financial indicators, and ignored the application of nonfinancial indicators, so that they could not carry out reasonable and effective supervision and assessment of their public welfare functions and social functions.

\section{The Assessment is Subjective}

Some the state-owned enterprises simplify the assessment level, but have not worked out the exact standard to judge the application of assessment level, so they can't achieve the fair and impartial at all. In most cases, examiners are influenced by personal preferences, scoring according to their own impressions and subjective judgments and unconvincing.

\section{EXPERIENCE OF FOREIGN STATE ENTERPRISE ASSESSMENT}

At the end of the 20 period, the activities of total quality management and business process reengineering rise abroad. In the performance evaluation of the state-owned enterprises, the overall performance was paid more attention rather than the achievement of the financial goals in the past. In the assessment method, it is divided into two kinds. Most of the organizational assessment adopts the Key performance indicators method and the balance-records method. The objective management and the 360 degree feedback are mostly used for the individual assessment.

Britain is one of the western countries that pay close attention to the performance evaluation of the state-owned enterprises. In 1978, the white paper issued by the British government attached great importance to the formula and expression of the operating indexes in the annual report of the state-owned enterprises, this measure promoted the institutionalized construction of the enterprises' public operating indexes and the development of their own management evaluation. The evaluation and assessment of the performance of the state-owned enterprises includes three aspects: the first is the financial indicators, the net assets yield is the main; the two is the external financing limit, that is the maximum amount of external loans and appropriations for the enterprise in a given year; the three is the operating target, and the main is cost reduction. The main administration to evaluate the state-owned enterprises is the monopoly and merger Committee (MMC). From the point of view of practice, although the performance evaluation of the British's state-owned enterprises has not formed a more complete theoretical system yet, it has shown more 
characteristics of comparing business objectives and performance assessment.

In 1980s, France began to carry out the management of the planned contract system for the monopolistic the stateowned enterprises. In the contract, the obligations and responsibilities of the government and enterprises were stipulated. The most important evaluation of the performance of the enterprise was the implementation of the planned contract. Some planned contract also stipulates evaluation index, which mainly includes three aspects, such as cost input and productivity index, commercial service index and product quality index. Every year, the Superior Department, the Ministry of Finance and the Audit Bureau should assess the implementation of the related planned contract indicators of the state-owned enterprises, and to reward or punish the top executives of the state-owned enterprises accordingly.

Other countries, such as Germany, Italy, New Zealand and other countries, also carry out business performance evaluation for the state-owned enterprises. Because the stateowned enterprises generally have two characteristics -"publicity" and "enterprise nature", the Western governments' evaluation of the state-owned enterprises, especially non-profit enterprises, in addition to the commercial objectives, they should consider the contribution of the enterprise to the social interests and the relevant policy factors, and generally designate special organization to implement.

The assessment of the state-owned enterprises in China, while drawing on the experience of the developed countries, should combine the characteristics of our country by defining functions and classifying categories to carrying out classification reform, classified development, classified supervision, classification and responsibility and classification assessment, so as to improve the pertinence of the reform, the effectiveness of supervision and evaluation. These measures will promote the integration of state-owned enterprises and market economy, and promote their organic integration of economic and social benefits.

\section{SET UP A REASONABLE AND EFFICIENT INDEX SYSTEM FOR CLASSIFIED EXAMINATION AND EVALUATION OF THE STATE-OWNED ENTERPRISES}

The evaluation index system of the state-owned enterprises refers to the factors that reflect the characteristics of evaluation objects according to the needs of the performance evaluation target and the evaluation subject, which are reflected in the form of the index. The thinking of assessment work is divided into two parts. The first, the indicators of assessment can be quantified as much as possible and the quantity should concise. The second, the content indicators of assessment should conform to the actual characteristics of enterprises and the index system should be targeted and consistent with the enterprise's own management. According to the requirements of classified assessment, different types' enterprises should set up different indicators for annual performance evaluation. Index system includes annual performance indicators and term of office performance indicators.

\section{A. Market Competitive Enterprises}

Because such enterprises are fully competitive in the industry and mainly perform the market management responsibilities, they should focus on their profitability, capital income and risk control ability. Evaluation index can use economic indicators and asset safety indicators. The first, for economic benefit indicators, we can use the total profit or attributable to the parent company's net profit, net assets yield and other financial indicators. The target value of index is in principle not less than the actual completion value of previous year or the average value of evaluation index completed in the previous three years, which is independently declared by the assessed enterprise and determined by the examination committee. The factors that should be considered in the examination and determination include the changes in objective factors, such as the additional investment of parent company, the revaluation of land and fixed assets, the adjustment of assets, the cancellation of previous annual latent losses and other factors determined by the assessment committee; The impact of the income of treatment of the non-current assets and the return of investment in the disposal of financial assets, the compensation for the government's demolition and the impact of other major non-recurrent gains on the target value. The second, asset safety index can use asset liability ratio and financing comprehensive financial cost to guide enterprises to control financial risk and financial cost. The target value of asset liability ratio should be set up in accordance with the specific circumstances of assessed enterprise, involving the group additional investment or the index of the transfer of assets, which should be adjusted. The target value of financial cost of comprehensive financing should be based on the cost level of the previous year (the first three years before the general examination). The group's capital management measures should be adjusted comprehensively, involving factors such as financing environment and macro policy adjustment. The weight of economic indicators should be higher than the weight of asset safety index in order to guide enterprises to create economic benefits.

\section{B. Public Welfare Enterprises}

From the perspective of public welfare state-owned enterprises, its core social function is to provide reliable public products and services and complete the specific policy goals assigned by the country. Accordingly, the core social responsibility of this kind of enterprise is effective and efficient supply of public goods and services, the obligation of universal service, the responsibility of safety production and social security, the responsibility of low carbon environmental protection and treating each stakeholder responsibly. The evaluation and assessment must also be guided by the creation of pure social value. It mainly evaluates the supply of public products and services, product standards and quality of, manufacturing costs and the pricing of fairness. 


\section{The Specific Functional State-owned Enterprises}

Such enterprises are the combination of public welfare state owned enterprises and general commercial state owned enterprises. In the actual work, it is relatively difficult to assess such the state-owned enterprises, but this specific functional state-owned enterprises are in a large number of exist in the society. In the classification assessment of the state-owned enterprises, the classification of enterprise' main business should be determined by the method of weighting, and we have to take the corresponding assessment model. Then the different business contents should be classified and discussed, and different evaluation models are established. On the basis of the overall requirements, we should on the basis of ensuring reasonable returns and value maintenance and appreciation of state-owned capital to strengthen the assessment of national service strategy and completion of major special tasks.

\section{CONCLUSION}

According to the national conditions of our country, the implementation of the relevant state laws and state capital supervision, the safety production, the construction of honest administration and so on must also have a certain proportion. It must be noted that the evaluation index system of enterprise is not constant. With the change of the function of enterprise and the task, the evaluation subject should adjust evaluation index dynamically so as to give play to the guiding role of evaluation index, so that the state-owned enterprises should be better obedient to the overall situation of national economic construction.

\section{REFERENCES}

[1] Hao Jundong. Suggestions on Improving the Performance Appraisal System of State Owned Enterprises[J].PIM Forum,2009:37-39.

[2] Song Linqian. Research on Reasonable Performance Appraisal Indicators for State Owned Enterprises[J].Market Modernization,2010(34).

[3] Gao Minghua.The Classification Reform of State-owned Enterprises Must Correspond to the Classification Supervision of National Capital[J]. Theoretical Research,2014(2): 44-46.

[4] Jin Pei.On the Reorientation of State-owned Wnterprises Reform [J].Xinhua News Digest,2010(13).

[5] Qiu Weinian,Lin Jiarong,Linming. Enlightenment from the Reform of State Owned Enterprises in the US and France on the Development and Transformation of State Owned Enterprises in China.Special Zone Economy,2011(08) 1004-0714.

[6] Wang Hongbo,Tao Huiming. Comparison of the Nature and Function of Chinese and Western State Owned Enterprises[J]. Leadin Journal of Ideological \& Theoretical Education,2015(7): 74-82.

[7] Zhou Na,Zhuang Lingling. Functional Orientation of the New Round of SOE Reform: Comparison between Shanghai and Chongqing City Investment Group[J].Reform,2016(2): 116-124.

[8] Wang Weizhong. The Framework Design of Three Levels of the Reform of State Owned Enterprises[J].Dongyue Tribune,2016(3):143-151. 